\title{
THE SOCIETY FOR THE HISTORY OF ECONOMIC THOUGHT OF JAPAN
}

\author{
Annual Meeting 1988 and the Regional Activities
}

by

\section{Toshihiro Tanaka. Kwansei Gakuin University}

The annual meeting for 1988 was held at Senshu University. Tokyo on 5-6 November. The common theme of the meeting was 'The Formation of Political Economy: the case of James Steuart' on which the following three papers were read after the introductory remarks by Noboru Kobayashi under the charimanship of him and Shigeshi Wada.

1. Theoretical construction of the First Monetary Economics (Ikuo Omori).

2. Discovery of Modern Society by Political Economy (Hiroshi Takemoto).

3. 'The Crisis of Modern Society' in Sir J. Steuart and the Formation of Political Economy (Nobuyoshi Kawashima).

In addition. the following thirteen papers and a special paper were presented.

1. Theories of Capital and Value in Ricardian Economics (Masashi Izumo).

2. The Historical Place of Gossen's Theory of Value (Masahiro Kawamata).

3. The Structure of Theory of Value in Ricardo and J.S. Mill (Yasunori Fukagai).

4. J. Anderson on the Economic Development of Scottish Highlands (Masatomo lizuka).

5. Malthus's Essay on the Principles of Population and Principles of Political Economy (Yasuyuki Nakanishi).

6. The Communistic Thought of Theodore Dézamy: In relation to the formation of Marx's early thought (Masayuki Nagayama).

7. The Fiscal Policy Ideas of C. Davenant (Masao Okura).

8. Yukichi Fukuzawa's View of Business (Yukio Cho).

9. Keynes's Theory of Money and Prices: Centering on chapter 21 of General Theory (Toshihiro Nakaya).

10. The Structure of Richardo's Theory of Machinery (Tomikazu Hoshino). 
11. The Aristotelian Tradition in Economic Understanding of Society (Daisuke Arie).

12. On Richardo's Theory of Value: Theoretical Structure of the first chapter of the Principles (Susumu Takenaga).

13. The Viewpoint and Method of Social Economics in M. Weber (Yoshihisa Usami).

14. Special paper: The Growth of Political Economy in Eighteenth Century Britain (J.G.A. Pocock. Johns Hopkins University).

Professor Yoshiki Yoshizawa. Senshu University was elected as the next president with the other directors. His two-year presidency will begin from April 1989 to succeed Professor M. Tanaka.

The next annual meeting will be held at Kyushu University on 4-5 November 1989.

\section{Regional Meetings:}

The following regional meetings have been held since the meetings previously reported.

The Kanto Branch:

On 19 March at Nihon University two papers were read:

1. W.C. Mitchell on Social Intelligence: Relation to J. Dewey`s Thought (Hiroyuki Saito).

2. Tooke's History of Prices and Political Economy Club (Tomoyoshi Fujitsuka).

On 4 June at Nihon University Professor Donald Winch's following special lecture was given.

The Enlightenment and the Science of Legislator (University of Sussex. U.K.)

\section{The Kansai Branch:}

On 30 January. 1988 at Kobe University two papers were read:

1. The Structure and Significance of Malthus's Theory of Population Wave Motion (Yasuyuki Nakanishi).

2. On the understanding of poverty problem in Britain in the end of the 19th century (Norio Anpo).

On 28 May at Osaka Prefectural University the following two papers and a special lecture by Professor D. Winch were given:

1. John Law's theory of credit (Tatsuro Nikaido).

2. Keynes's Theory and Loanable Funds Theory (Yoshitaka Hattori). 
3. Special Lecture: The Uses and Abuses of the History of the Social Sciences (Donald Winch. University of Sussex, U.K.).

On 10 September at Aichi Gakuin University two papers were read:

1. Some Points in the Formation of Young J.S. Mill's Thought: From his mental crisis to about 1840 (Tomonori Yamabe).

2. The Present-day Significance of I.H. Parvus's Theory of Imperialism (Yoshiaki Tanaka).

\section{The Seinan Branch:}

On 20-21 February, 1988 at Kurume University the following five papers were presented:

1. Economics of Keynes and Keynsians (Eiji Oyano).

2. The Formation of Keynes's Tract on Monetary Reform (Norio Suzuki).

3. J. Anderson`s Observations: Its central theme and construction (Masatomo Iizuka).

4. The Formation Process of Marx's Early Thought (Naoki Hashimoto).

5. The Significance of the Great Men of Exile (Naoki Hashimoto).

On 9-10 July at Hiroshima University four papers were read:

1. On the Economic Improvement Ideas in Scotland in the 1730's: Centered on P. Linsay and T. Melvill (Gentaro Seki).

2. On A. Marshall's Quasi Rent (Noburo Iwashita).

3. Neo-classical Methodology and Keynes`s Methodology (Tadashi Datai).

4. 'The Crisis of Modern Society' in Sir J. Steuart and the Formation of Political Economy (Nobuyoshi Kawashima).

\section{The Tohoku Branch:}

On 18 June. 1988 at Yamagata University two papers were read:

1. The two editions of J.G. Eccarius"s "A Working Man's Refutation of Some Points of Political Economy Endorsed and Advocated by John Stuart Mill ${ }^{\circ}$ and new MEGA editing (Shigeru Arakawa).

2. The Three Origins of Marxism: Centering on Economic and Philosophic Manuscripts (Koichi Hata). 


\title{
THE HISTORY OF ECONOMIC THOUGHT SOCIETY OF AUSTRALIA
}

\author{
Inaugurated in May 1981
}

$\begin{array}{lll}\begin{array}{l}\text { President } \\ \text { Secretary- } \\ \text { Treasury }\end{array} & \text { P.D. Groenewegen } & \text { University of Sydney } \\ \text { Editor of the } & \text { R. Petridis } & \text { Murdoch University } \\ \text { HETSA BULLETIN } & \text { J. Pullen } & \text { University of New England } \\ \text { Editoral Board } & \text { T. Endres } & \text { University of Auckland. N.Z. } \\ & \text { P. Groenewegen } & \text { University of Sydney } \\ & \text { R. Petridis } & \text { Murdoch University } \\ & \text { M. Schneider } & \text { La Trobe University } \\ & \text { M. White } & \text { Monash University }\end{array}$

Correspondence relating to membership and subscriptions should be sent to R. Petridis, Secretary/Treasurer HETSA. Economics Programme. Murdoch University, Murdoch. Western Australia 6150. The membership fee is (Aust) $\$ 15$ per annum. and includes a subscription to the HETSA BULLETIN.

Contributions to the HETSA BULLETIN (articles, notices, book reviews, and books for review) should be sent to J. Pullen. Editor, HETSA BULLETIN, Department of Economics, University of New England. Armidale. N.S.W. 2351.

Recent articles in the HETSA BULLETIN include:

M.P. Carter The Compleat Historian of Economic Thought

M. White Jevons" Charge of "The Noxious Influence of Authority:" A Note

J. Lodewijks Teaching and Examining the History of Economic Thought at Duke University

J. Pullen Reminiscences of Patricia James (1917-1987)

Peter Groenewegen Alfred Marshall and Australian Economics

Michael V. White "That God-Forgotten Thornton" and the Laws of Supply and Demand

John Lodewijks The Division of Labour Economics 


\title{
NOTICE TO HES MEMBERS
}

Members are asked to send suggestions for nominations for officers of the Society (President Elect. Vice President. Secretary-Treasurer) and members of the Executive Committee for 1990-91 to the Chair of the Nominating Committee at the following address:

\author{
Professor Abraham Hirsch \\ 41 Beverly Road \\ Upper Montclair \\ New Jersey 07043. USA
}

Members are also asked to send suggestions for possible Distinguished Fellows to the Chair of the Distinguished Fellows Committee at the following address:

\author{
Professor D.E. Moggridge \\ Department of Economics \\ University of Toronto \\ $150 \mathrm{St}$. George Street \\ Toronto. Canada M5S 1A I
}

Suggestions should be received by the Committee before September 1. 1989 and it would assist the Committee if suggestions are accompanied by a reasoned statement (including a bibliography) of the grounds for the suggestion.

\section{ASSOCIATION CHARLES GIDE POUR L'ETUDE DE LA PENSEE ECONOMIQUE}

The "Association Charles Gide pour l'Etude de la Pensèe Economique" is a professional organization of French-speaking economists with an interest in the history of economic thought and the philosophy of economics.

Every other year, it organizes a major conference. The first one (Montpellier 1985) was devoted to "Scientific Revolutions in Economics. " while the second one (Nice 1987) focused on the "History of Monetary Theory. " A third Conference is due to take place in Strasbourg on September 20-21. 1989. The topic selected is "Emergence and Foundations of the Concept of Equilibrium in Economics."

The Association also sponsors smaller symposia (for example. on the Philosophy of Economic Science (Mons. December 1987), on Léon Walras (Lyon. June 1988). It publishes Les Cahiers de l'AC.G.E.P.E. and circulates a newsletter twice a year. 


\section{STUDIES IN THE HISTORY OF ECONOMICS}

The History of Economics Society and MacMillan have come to an agreement to jointly publish a refereed series of monographs in the history of economics.

The series will be under the editorship of D.E. Moggridge. who will be advised by an editorial advisory board consisting of:
N. de Marchi (Duke University and University of Amsterdam)
D. Patinkin (Hebrew University of Jerusalem)
B. Sandelin (University of Lund)
Y. Shionoya (Hitotsubashi University)
D.A. Walker (Indiana University of Pennsylvania)
J.K. Whitaker (University of Virginia)
D. Winch (University of Sussex)

Individuals interested in submitting manuscripts should contact in the first instance:

Professor D.E. Moggridge.

St. John's College.

Cambridge. CB2 1TP. (until 31 July 1989)

ENGLAND

Department of Economics.

University of Toronto.

150 St. George Street.

(after 31 July 1989)

Toronto. Ontario.

CANADA.

M5S 1A1 


\title{
ANNUAL CONFERENCE ON ECONOMIC ISSUES
}

\section{April 1990}

\section{Call for Papers}

Middlebury College's Annual Conference on Economic Issues will be entitled "Educating Economists." It will consider the nature of incentives in economic education at the undergraduate and graduate level. Some desired paper topics include: a study of graduate school dropouts; an empirical survey of economic education: and a societal cost benefit analysis of graduate economic education. Anyone interested in presenting a paper should send a summary of their proposed paper to:

\author{
David Colander \\ Department of Economics \\ Middlebury College \\ Middlebury, Vermont 05753
}




\title{
APPEL A CONTRIBUTION
}

\section{COLLOQUE LA PENSEE ECONOMIQUE PENDANT LA REVOLUTION FRANÇAISE TRADITION OU INNOVATION?}

\author{
Musce te la Révolution française \\ Cháteau de - aille $6-7-8$ septembre 1989
}

La dimension politique de la Révnlution française a beaucoup été étudiée. Elle suscite encore de nombreux débats qui continuent de jeter leur ombre sur presque tous les aspects de cette période décisive de notre histoire.

Malgré quelques études fragmentaires, la pensée économique fait partie de ces domaines délaissés dont on commence à peine a soupçonner les richesses: tout se passe en effet comme si, de François Quesnay et Turgot à Jean-Baptiste Say, il ne s'était rien produit de marquant au plan théorique. Pourtant, de 1789 à 1803, les écrits économiques furent nombreux et multiformes. embrassant tous les aspects des problèmes débattus dans les assemblées.

Ce colloque se propose de remettre au jour ces écrits, de les replacer dans leur contexte, d'en juger la portée et la signification pour l'histoire de la pensée économique et pour les liens qu'elle entretient avec les autres disciplines. Il a aussi pour but de rendre compte de l'écho qu'a pu avoir la Révolution française parmi les économistes contemporains étrangers et, plus tard, parmi les économistes français eux-mèmes. Son ambition consiste donc à amorcer une réflexion approfondie sur ces thèmes et peutêtre, incidemment, parviendra-t-ll à dégager les raisons qui ont pu conduire ja piupart des historiens de la pensée économique à négliger cette période.

\section{Comite de programme}

Le comite de programme est compose de Richard Arena (Universite de Nice), Amaud Bethoud (Universite de Paris $X$ Nanterre), Gilbert Faccarello (Université du Maine). Andre Lapidus (Universite de Picardie), Jean Rosio (Université d'Aix-Morseille), Raymond Tortajada (Université des sciences sociales de Grenoble), Pbillppe Stejner (Université de Paris-Dauphine), Paul Vidonne (Université des sciences sociales de Grenoble), Jacques Wolf (Universite Pantheon-Sorbonne)

$A$ adresser d:

Gilbert Faccarello, Uaiversite du Maine, BP 535, 72017 Le Mans cedex

Paul Vidonne, Universite des sciences sociales de Grenoble, 47X, 38040 Grenoble cedex 
Now Available From

Edward Elgar Publishing Company

\title{
PERSPECTIVES ON THE HISTORY OF ECONOMIC THOUGHT
}

\author{
Selected Papers from the
}

History of Economics Society Conference 1987

Edited by Donald A. Walker, Professor and Chairperson of the

Department of Economics, Indiana University of Pennsylvania.

This major two volume work comprises a carefully edited selection of new essays presented at the History of Economics Society Conference in 1987. It marks the beginning of an annual publication which will promote high quality, scholarly work in the field of the history of economic thought.

Volume One contains papers on the classical and neoclassical schools of economic thought. Many of these papers are relevant for current economic studies and all of them reveal how classical and neoclassical economics have had an impact on subsequent doctrinal or practical developments.

The second volume deals with the contributions of some economists to the policies of specific countries, providing examples of how economic theories have been used in the formulation of practical proposals. Included are five papers which review aspects of the work of J. M. Keynes. Other papers analyze modern economic topics: the history of neutral money, monetarism in Holland, the real-balance effect and the rational expectations hypothesis. The papers correct errors of interpretation and undertake constructive analyses. They show the importance of studies of the history of economic thought for an understanding of its influence on our conceptions of the world and on economic, social and political behavior.

\section{216pp. \$42.95 Volume One \\ 1852781327 256pp. \$48.95 Volume Two}

For more information or a complete catalog, please write to:

Edward Elgar Publishing Company

Old Post Road

Brookfield, VT 05036

Call (802) 276-3162 or FAX (802) 276-3837

\section{SPECIAL DISCOUNT TO HES MEMBERS!!}

Edward Elgar Publishing Company will be offering a special 20\% discount on Perspectives on the History of Economic Thought to all HES members. When you place your order, simply mention the code "C08" and you will receive $20 \%$ off the listed price! This special offer expires May 31, 1989 so order your copies of these exceptional books today. 